\title{
Calculation Of Coliform Number Using Most Probable Number (MPN) Methods On Soy Milk Sold in Pogot Area Of Surabaya
}

\author{
Rachma Khairun Nisaa*, L. Soedjoto, Baterun Kunsah \\ Health Analyst, Universitas Muhammadiyah Surabaya-Indonesia. \\ *Corresponding author: Rachma9703@gmail.com
}

\begin{abstract}
The quality of drinks is one of the problems that exist in society, especially because of bacterial contamination of drinks that often occurs in developing countries. One of them is soy milk drinks that are contaminated by bacteria including those sold by street vendors in the Pogot area of Surabaya. Based on the background description in this study can be formulated as follows: Is the number of Most Probable Number (MPN) Coliform in soy milk sold by street vendors in the Pogot area of Surabaya fulfill the Indonesian National Standard (SNI) 7388: 2009? The purpose of this study was to determine the amount of Coliform in soy milk sold by street vendors in the Pogot area of Surabaya compared to the Indonesian National Standard (SNI) 7388: 2009 regarding the maximum limit of microbial contamination in food. This study used a descriptive study design that soy milk sold by street vendors in the Pogot area of Surabaya was the population. Samples were used as many as 16 samples from 4 street vendors, each of which was taken 4 then laboratory-tested and analyzed using percentages. Based on the requirements of the Indonesian National Standard (SNI) 7388: 2009, the limit of contamination of the Most Probable Number (MPN) Coliform in soy milk is $20 / \mathrm{ml}$. Based on the results of the research of 4 soy milk traders there were 2 traders whose the results fulfilled the requirements of the Indonesian National Standard (SNI) and 2 traders whose the results didn't fulfill the requirements of the Indonesian National Standard (SNI). So 50\% were eligible (MS) and 50\% were not eligible (TMS).
\end{abstract}

Key words: Coliform Bacteria, Most Probable Number (MPN), Soy Milk.

\section{INTRODUCTION}

Soy milk is a product that is rich in vitamins and minerals, also very economical, lactose free, very easy to digest. Cholesterol-free soy milk with very low fat content and rich in phospholipid unsaturated fatty acids, especially lecithin and linolenic acid. Soy milk is one of the processing products which is the result of soybean extraction. Soy milk protein has an amino acid structure similar to cow's milk, so soy milk is often used as a place for cow's milk. In addition, soy milk also contains fat, carbohydrates, phosphorus, iron, provitamin A, vitamin B complex except B12 (Singh, 2010).

Soy milk is a popular drink, until now it can be said that soy milk has quite a lot of enthusiasts and has started to spread to various marketing venues, ranging from city buses which are served modestly by only in plastic wrappers to supermarkets in more packaging. has a selling value such as in bottles, etc. (Anonim, 2012). 
Soy milk can provide benefits for the health of the body and can also cause poisoning. A case of soy milk poisoning has occurred in elementary school children, quoted from JawaPos.com (Miftakhul, 2017). School snacks have claimed another victim. This time the victims were students of SDN Brodot 1, Bandar Kendungmulyo District, Jombang Regency. It is suspected that the soy milk they bought in front of the school caused 13 students to be poisoned, so they had to be rushed to the local Puskesmas for intensive care. It is suspected that the poisoning was caused by contamination of soy milk.

Field evidence is based on the Pracoyo survey in 2006, contamination by pathogenic bacteria in food and beverages often occurs, with a contamination level of $24-48 \%$, including Salmonella group E, Staphylococcus aureus, Pseudomonas sp., E. Coli, dan Bacillus sp.

Contamination of microorganisms in soy milk can be obtained from the use of tools in the manufacture of dirty processes, dirt around the processing container and the raw material itself which is not hygienic and dust or other factors that can cause contamination of the soy milk. . With this contamination, it causes damage to the quality of soy milk so that soy milk is not suitable for consumption by consumers (Helpida, 2013).

The higher the level of Coliform bacteria contamination, the higher the risk of the presence of other pathogenic bacteria that usually live in human and animal feces. One example of pathogenic bacteria that may be present in beverages contaminated with human and warm-blooded animal feces is E. Coli, a microbe that causes symptoms of diarrhea, fever, stomach cramps and vomiting (Entjang, 2003).

Escherichia coli bacteria are included in the Coliform group, this type of bacteria is used as an indicator organism for food and drink contaminated by human and animal feces because it is easy to see in a simple way. The discovery of $E$. coli does not mean that there are pathogens in the water. Coliform is a group of bacteria that is used as an indicator of dirt pollution and bad conditions for water, food and milk drinks. The presence of Coliform bacteria in food or beverages supports the possibility of microbes that are enteropathogenic and toxic which are harmful to health. The Coliform genus includes: Serratia, Hafnia, Citrobacter, Enterobacter, Klebsiella, dan E. coli (Pelczar and Chan, 2005).

Coliform bacteria were found in food and beverages, it has not been confirmed that there was contamination by pathogenic bacteria, but if the number of Coliform bacteria exceeds the maximum limit of contamination in food, it can cause various diseases.

According to the Standard National Indonesian (SNI) 7388: 2009 the limit of the Most Probable Number (MPN) Coliform in soy milk is $20 / \mathrm{ml}$. Based on the description above, it encourages the author to take the title of research on calculating the amount of Coliform using the Most Probable Number (MPN) method on soy milk sold by street vendors in the Pogot area of Surabaya. 


\section{METHODS}

This study used a descriptive research design street vendors in the Pogot area of Surabaya. to obtain an objective picture of the amount of Coliform using the MOST PROBABLE The sample used was soy milk sold by street vendors in the Pogot area of Surabaya, as many NUMBER (MPN) method on soy milk sold by street vendors in the Pogot area of Surabaya. as 16 samples from 4 street vendors, each of which was 4.

The study population was soy milk sold by

\section{RESULTS}

Based on the Coliform examination with the Most Probable Number (MPN) method on 16 Pogot area of Surabaya, 4 samples each were taken, the results were shown in Table 4.1 as samples of soy milk from 4 street vendors in the follows:

Table 1. Examination Results of Presumptive Tests and Confirmative Tests of Most Probable Number (MPN) Coliform From 16 Soy Milk Samples.

\begin{tabular}{|c|c|c|c|c|c|c|c|c|c|c|c|c|}
\hline \multirow[t]{2}{*}{ No } & \multirow[t]{2}{*}{$\begin{array}{l}\text { Sample } \\
\text { Code }\end{array}$} & \multicolumn{3}{|c|}{ Test Presumtif LB } & \multirow[t]{2}{*}{ Result } & \multicolumn{3}{|c|}{$\begin{array}{c}\text { Test Confirmatif } \\
\text { BGLB }\end{array}$} & \multirow[t]{2}{*}{$\begin{array}{l}\text { Result } \\
\text { MPN } \\
\text { Index }\end{array}$} & \multirow[t]{2}{*}{$\begin{array}{c}\text { Result } \\
\text { Average } \\
\text { MPN }\end{array}$} & \multirow[t]{2}{*}{ Qualified } & \multirow[t]{2}{*}{$\begin{array}{l}\text { Unqualifi } \\
\text { ed }\end{array}$} \\
\hline & & $\begin{array}{l}5 \mathrm{x} \\
10 \\
\mathrm{ml}\end{array}$ & $\begin{array}{c}1 \mathrm{x} \\
1 \mathrm{ml}\end{array}$ & $\begin{array}{l}1 \mathrm{x} \\
0.1 \\
\mathrm{ml}\end{array}$ & & $\begin{array}{c}5 \mathrm{x} \\
10 \\
\mathrm{ml}\end{array}$ & $\begin{array}{c}1 \mathrm{x} \\
1 \mathrm{ml}\end{array}$ & $\begin{array}{l}1 \mathrm{x} \\
0.1 \\
\mathrm{ml}\end{array}$ & & & & \\
\hline 1. & $\mathrm{~A} 1$ & $5+$ & $1+$ & $1+$ & + & 0 & 0 & $1+$ & 2 & \multirow{4}{*}{11,8} & \multirow{4}{*}{$\sqrt{ }$} & \\
\hline 2. & A2 & $5+$ & $1+$ & $1+$ & + & $1+$ & 0 & 0 & 2,2 & & & \\
\hline 3. & A3 & $5+$ & $1+$ & $1+$ & + & $3+$ & $1+$ & $1+$ & 16 & & & \\
\hline 4. & A4 & $5+$ & $1+$ & $1+$ & + & $4+$ & $1+$ & $1+$ & 27 & & & \\
\hline 5. & B1 & $5+$ & $1+$ & 0 & + & $4+$ & $1+$ & 0 & 21 & \multirow{4}{*}{16,7} & \multirow{4}{*}{$\checkmark$} & \\
\hline 6. & B2 & $5+$ & 0 & 0 & + & $3+$ & 0 & 0 & 8,8 & & & \\
\hline 7. & B3 & $5+$ & $1+$ & $1+$ & + & $4+$ & $1+$ & $1+$ & 27 & & & \\
\hline 8. & B4 & $5+$ & $1+$ & $1+$ & + & $2+$ & $1+$ & $1+$ & 10 & & & \\
\hline 9. & $\mathrm{C} 1$ & $5+$ & $1+$ & 0 & + & $3+$ & $1+$ & 0 & 12 & \multirow{4}{*}{20,25} & & \multirow{4}{*}{$\sqrt{ }$} \\
\hline 10. & $\mathrm{C} 2$ & $5+$ & $1+$ & 0 & + & $4+$ & $1+$ & 0 & 21 & & & \\
\hline 11. & C3 & $5+$ & $1+$ & $1+$ & + & $4+$ & $1+$ & 0 & 21 & & & \\
\hline 12. & $\mathrm{C} 4$ & $5+$ & $1+$ & $1+$ & + & $4+$ & $1+$ & $1+$ & 27 & & & \\
\hline 13. & D1 & $5+$ & $1+$ & $1+$ & + & $5+$ & $1+$ & $0+$ & 240 & $\geq 240$ & & $\sqrt{ }$ \\
\hline
\end{tabular}

After carrying out the presumptive test (estimated) incubated at $370 \mathrm{C}$ for $1 \mathrm{X} 24$ hours, a positive result $(+)$ was obtained which was then continued on the Confirmative test (confirmation) Most Probable Number (MPN) Coliform.
In the results of the Most Probable Number (MPN) Coliform that meets the requirements and does not meet the requirements of the Indonesian National Standard (SNI) $20 / \mathrm{ml}$ Number: 7388 of 2009, the results are shown in Table 2 as follows: 
Table 2. Most Probable Number (MPN) Coliform Examination Results that meet the requirements and do not meet the requirements of the Standard National Indonesian (SNI) 20/ml Number: 7388 of 2009.

\begin{tabular}{|c|c|c|c|c|c|}
\hline No & $\begin{array}{c}\text { Sampl } \\
\text { e } \\
\text { Code }\end{array}$ & $\begin{array}{l}\text { Result } \\
\text { MPN } \\
\text { Index }\end{array}$ & $\begin{array}{c}\text { Result } \\
\text { Average }\end{array}$ & Qualified & $\begin{array}{c}\text { Unqualifi } \\
\text { ed }\end{array}$ \\
\hline 1. & $\mathrm{~A} 1$ & 2 & \multirow{4}{*}{11,8} & \multirow{4}{*}{$\sqrt{ }$} & \\
\hline 2. & $\mathrm{~A} 2$ & 2,2 & & & \\
\hline 3. & $\mathrm{~A} 3$ & 16 & & & \\
\hline 4 & $\mathrm{~A} 4$ & 27 & & & \\
\hline 5. & B1 & 21 & \multirow{4}{*}{16,7} & \multirow{4}{*}{$\sqrt{ }$} & \\
\hline 6. & B2 & 8,8 & & & \\
\hline 7. & B3 & 27 & & & \\
\hline 8. & B4 & 10 & & & \\
\hline 9. & $\mathrm{C} 1$ & 12 & \multirow{4}{*}{20,25} & & \multirow{4}{*}{$\checkmark$} \\
\hline 10. & $\mathrm{C} 2$ & 21 & & & \\
\hline 11. & C3 & 21 & & & \\
\hline 12. & $\mathrm{C} 4$ & 27 & & & \\
\hline 13. & D1 & 240 & \multirow{4}{*}{$\geq 240$} & & \multirow{4}{*}{$\checkmark$} \\
\hline 14. & $\mathrm{D} 2$ & $\geq 240$ & & & \\
\hline 15. & D3 & $\geq 240$ & & & \\
\hline 16. & D4 & $\geq 240$ & & & \\
\hline
\end{tabular}

Information:

Q : : Qualified

NQ : Unqualified

LB : Lactose Broth

BGLB : Brilliant Green Lactose Broth

From the results of the above research, the presented in the form of a percentage obtained results of the examination of the Most Probable can be shown in Table 2. as follows:

Number (MPN) Coliform in the sample are

Table 2. Results of Frequency and Percentage that Meet the Requirements and Not Meet the Requirements in the Inspection of the Most Probable Number (MPN) Coliform Standard National Indonesia (SNI) 20/ml Number:7388 of 2009.

\begin{tabular}{|c|c|c|c|c|}
\hline Explanation & Q & $\%$ & NQ & $\%$ \\
\hline Soy Milk & 2 & 50 & 2 & 50 \\
\hline
\end{tabular}

Of the 16 samples, each sample was taken 4 soy milk samples obtained from 4 street vendors, the results obtained were samples that met the requirements and samples that did not meet the requirements of the Indonesian National Standard (SNI) Number 7388 of 2009, the Most Probable Number (MPN) contamination limit. Coliform in soy milk is $20 / \mathrm{ml}$.

\section{DISCUSSION}

According to the requirements of the Standard National Indonesian (SNI) Number 7388 of 2009, the most probable number (MPN) coliform contamination limit in soy milk is 20/ml. The Presumptive and Confirmative Results of the Most Probable Number (MPN) Coliform examination on soy milk of street vendors in the Pogot area are presented in table 4.1, then the results of the Most Probable Number (MPN) table are in table 2. Based on the research in terms of bacteriology, it shows that 50\% meet the requirements and 50\% do not meet the requirements. Of the 16 samples of soy milk sold by 4 street vendors in the Pogot area of Surabaya, after the results from the MPN table are averaged, there are 2 samples that meet the requirements (MS) and 2 samples that do not meet the requirements (TMS) of the Indonesian National Standard (SNI) ) Number 7388 of 2009. In previous studies in different 
locations also revealed about the sanitation hygiene of milk processing with the E. Coli bacterial test, which was branded as a result of 10 samples, there was 1 sample that did not meet the requirements or contained Coliform bacteria that exceeded the normal threshold. but negative for E. Coli (Deni, 2012).

The presence of Coliform bacteria in food and beverages indicates the possibility of microbes that are enteropathogenic or toxinogenic which are harmful to health. Coliform bacteria are divided into two groups, namely faecal Coliforms derived from animal or human feces, namely Escherichia coli and non-faecal Coliforms, namely Enterobacter aerogenosa which are usually found in dead animals and plants (Widiyanti et al, 2004). The high number of Coliform bacteria in soy milk can be influenced by many factors, such as contamination from the basic ingredients of making soy milk, water used, soy milk making tools, and environmental factors of sale. This factor can be a factor for the entry of bacteria (Buckle, et al. 2009).

Based on the research, it was conducted by using the presumptive test (estimator) first, where the presumptive test (estimator) was carried out using Lactosa Broth (LB) media and used seven test tubes in each sample. In a test tube containing Lactose Broth (LB) media, a durham tube is inserted upside down as a storage place for gas produced by bacterial metabolism. Lactose Broth (LB) filled with samples was then incubated at $37^{\circ} \mathrm{C}$ for $1 \times 24$ hours. The Lactose Broth (LB) medium in the soy milk sample, which was previously clear yellow after incubation, turned cloudy and there were bubbles in the durham tube. Based on the observations it can be said that the soy milk sample contains Coliform. According to Marsela (2015), Coliform is a gram-negative bacteria capable of fermenting lactose. This is what makes the media cloudy but also due to the formation of acids and gases in the durham tube. After the positive sample prediction test is carried out, it will be tested again at the next stage, namely the Confirmative test (confirmation) where the aim is to obtain more specific data regarding the type of Coliform contained therein. Confirmative test (affirmation) was carried out with Brothian Green Lactose Broth (BGLB) media with the same method in the prediction test. The BGLB media in soy milk samples obtained negative results. This could be because the bacteria that ferment lactose are not Coliform bacteria. This finding is almost the same as the previous study, but with different objects in Bungus District, Padang in 2012. In this study, one sample showed an MPN index> 1100, but the other sample showed an MPN index that matched the bacteriological requirements.

Factors that influence the results of this study are the presence of a turbidity factor in the soy milk sample so that during the presumptive test the sample in soy milk is too cloudy so it can be concluded that the soy milk sample is not a coliform germ and does not break down lactose so that it the confirmative test (confirmation) did not produce coliform germs therefore the results of the confirmative test (confirmation) were negative.

This research shows that the factors that can influence the basic ingredients of soybeans are the possibility of making soy milk water using PDAM water, the manufacturing process still 
using simple equipment, and the environment that is not far from around rivers and roads that are heavily polluted. In addition, there are several factors that influence soy milk, such as the use of bottles of soy milk that are used repeatedly and places where soy milk ingredients are often open so that dust, dirt, and

\section{CONCLUSION}

Based on the research results of 4 soy milk traders, there are 2 traders whose results meet the Indonesian National Standard (SNI) and 2 traders whose results do not meet the

\section{REFERENCES}

Adisarwanto, T. 2002. Budidaya Kedelai Tropika. Jakarta: Penebar Swadaya.

Andrianto, T. T dan N. Indarto. 2004. Budidaya dan Analisis Usaha Tani; Kedelai, Kacang Hijau, Kacang Panjang. Cetakan Pertama. Yogyakarta: Penerbit Absolut, Hal. 9-92. Dalam Skripsi M. Ikmal Tawakkal. P. 2009. Respon Pertumbuhan dan Hasil Produksi Beberapa Varietas Kedelai (Glycine Max L) Terhadap Pemberian Pupuk Kandang Kotoran Sapi. Universitas Sumatera Utara. Medan.

Astawan M. 2004. Sehat bersana aneka sehat pangan alami. Solo: Tiga serangkai.

Amrin, Totok. 2003. Susu Kedelai. Depok: Penebar Swadaya.

Anonim. 2007. Farmakologi dan Terapi. edisi 5. Departemen Farmakologi Terapeutik, Fakultas Kedokteran, Universitas Indonesia. pollution can enter and are likely to be contaminated. The discovery of Coliform bacteria in food and beverages does not necessarily cause disease, but if the number of bacteria exceeds the maximum limit, it is feared that other bacteria that are pathogenic in these materials can cause health problems.

Indonesian National Standard requirements. So 50\% Eligible (MS) and 50\% Unqualified (TMS).

Anonima ${ }^{a}$ 2012. Sekilas Tentang Susu Kedelai.Diaksesmelalui(http://www.sq uidoo.com//manfaat-susukedelai.)pada tanggal 23 Desember 2017.

Acton, Q.A., 2013. Advances in Gammaproteobacteria Reasearch and Application 2013th ed., Scholarly Edition, 2013. Available from : Google book [10 April 2016].

Adila, R., et al. 2013. Uji Antimikroba Curcuma spp. Terhadap Pertumbuhan Candida albicans, Staphylococcus aureus, dan Escherichia coli. Jurnal Biologi Universitas Andalas (J. Bio. UA.). Vol : 3 No :1

Buckle, K.A., R.A. Edward, G.H. Fleet dan Wootton. 2009. Ilmu Pangan. Jakarta: UI-Press.

Cahyono, B. 2007. Kedelai. CV. Semarang: Aneka Ilmu.

Diaksesmelalui(http://hansdw08.stude 
nt.ipb.ac.id/tag/kedelai-hitam/Hans)

pada tanggal 12 April 2018.

Entjang, I. 2003. Mikrobiologi dan Parasitologi untuk Akademi Keperawatan dan Sekolah Tenaga Kesehatan yang Sederajat. Bandung:Citra Adtya Bakti. Diaksesmelalui(https://ejournal.unsrat. ac.id/index.php/pharmacon/article/vie wFile/5450/4957) pada tanggal 9 April 2018.

Helpida, G.I. 2013. Uji Bakteriologis Susu Kedelai Produksi Rumah Tangga yang Di Jual Dipasaran .Skripsi. Padang : Biologi FMIPA, Universitas Negeri Padang.

Irianto, Koes. 2014. Bakteriologi, Mikologi dan Virologi Panduan Medis dan Klinis. Bandung: Alfabeta.

Irwan, A.W. 2006. Budidaya Tanaman Kedelai (Glycine $\max ($ L.) Merill). Bandung: Jurusan Budidaya Pertanian, Fakultas Pertanian, Universitas Padjadjaran, Jatinangor.

Jawetz dkk, 2001. Mikrobiologi Kedokteran. Jakarta: EGC Penerbit Buku Kedokteran.

Jawetz, E. dkk. 2005, Mikrobiologi Kedokteran. Edisi XXII. Jakarta: Salemba Medika. Kuntaraf, K. L. 2009. Makanan Sehat (12th ed). Bandung: Indonesia Publishing House. Miftakhul, F.S. 2017. Murid SD Keracunan Masal.

Diaksesmelalui(http://www.idola.jawapos.com /jpg-today/17/03/2017/muridsdkeracunan-masal) pada tanggal 14 Desember 2017.
Muchtadi, D. 2004. Gizi Untuk Bayi, ASI, Susu Formula dan Makanan Tambahan. Jakarta: Sinar Harapan.

Novianti, Y. 2012. Pengaruh Waktu Pemasakan dan Jenis Susu terhadap Sifat Organoleptik Permen Karamel Susu. (Skripsi). Bandar Lampung: Jurusan Teknologi Hasil Pertanian, Universitas Lampung.

Pelczar, M.J. dan Chan, E. C. S. 2006. DasarDasar Mikrobiologi Jilid 2. Jakarta: UI Press. Diaksesmelalui(https://core.ac.uk/do wnload/pdf/148610428.pdf) pada tanggal 01 April 2018.

Purnawijayanti, Hiasinta A. 2001. Sanitasi Higiene dan Keselamatan Kerja Dalam Pengolahan Makanan. Yogyakarta: Kanisius Media.

Pracoyo NE. dkk. 2006. Analisis Mikrobiologik Beberapa Jenis Makanan Jajanan (Moko). DKI Jakarta: CDK. Hal. 152: 41-42. Diaksesmelalui(http://ejournal.akbid-

purworejo.ac.id/index.php/jkk2/article/ view/46/44) pada tanggal 25 Desember 2017.

Prescott, el al. 2008. Mikrobiologi $7^{\text {th }}$ Edition. USA: McGraw-Hill Book Company.

Priyanti, Esteria. 2008. Perubahan Mutu Susu Kedelai Selama Pengolahan dan Penyimpanan. Semarang: Skripsi Fakultas Kedokteran Universitas Diponegoro.

Diaksesmelalui(https://core.ac.uk/dow nload/pdf/148613693.pdf) pada tanggal 03 Mei 2018. 
Sarwanto, A. 2008. Budidaya Kedelai Tropika.

Jakarta: Penebar Swadaya.

Septiatin, A. 2008. Meningkatkan Produksi Kedelai Dilahan Kering, Sawah, Dan Pasang Surut. Jakarta: Yrama Widya.

Singh, J. \& Singh, R. 2010.Optimization and Formulation of Orodiversible Tablets of Meloxin.Tropical Journal of Pharmacetical Research. 8(2): 153159.

Standar Nasional Indonesia.2009.Batas MaksimumCemaranMikrobadalamPan gan.BadanStandarisasiNasional Indonesia.

Widiyanti, N. L. P. M. dkk. 2004. Analisis Kualitatif Bakteri Koliform Pada Depo Air Minum Isi Ulang Di Kota Singaraja Bali. Jurnal Ekologi Kesehatan Vol 3(1) : 64-73. 